\title{
Effect of Training Form Method and Playing Method on the Basic Technical Capabilities of Football Players U-15
}

\author{
Ofroki*, Eddy Marheni, Afrizal. S \\ Students of Sports Coaching Education Study Program, Faculty of Sports \\ Science \\ Padang State University \\ Email: Ofroki13@gmail.com
}

\begin{abstract}
The research aims to find out 1) The Effect of Training Form Method on the Basic Technical Capabilities of U-15 Warriors FC Kayu Aro Kerinci Football. 2) The Influence of the Playing Method Method on the Basic Technical Capabilities of the U-15 Warriors FC Kayu Aro Kerinci Football. 3) The Difference between the Effect of Training Form Method and Playing Method on the Basic Technical Capabilities of U-15 Warriors FC Kayu Aro Kerinci Football. This type of research is a Quasi Experiment. The study design uses two groups pre-test and post-test involving 24 U-15 players The Research Instrument for Football Skill Tests: the set of tests that are put into effect are: 1) Dribbling, 2) Short Passed, 3) Throw in, 4) Running with the ball, 5) Heading the ball, 6) Shooting at the wall. Data analysis for testing the research hypothesis used a t-test with a significance level of $\alpha=0.05$. The results showed: 1) There was a significant effect on the Form of Training Method on the Capability of Basic Football Techniques, with (t count 3.97> $t$ table 1.80), 2) There is a significant influence on the Form of Playing Methods on the Basic Technical Capabilities of Football, with ( $t$ count 6.90> $t$ table 1.80), 3) There is a significant difference in effect between the effect of the Form of Training Method and the Form of Playing method on the Capabilities of Basic Football Techniques namely ( $t$ count 3.44 $>t$ table 1.80). The form of Playing Method shows better results in improving the necessary technical abilities of football.
\end{abstract}

Keywords - Training Form Method, Playing Method, football

\section{INTRODUCTION}

Football is a game played by two teams, each of which consists of eleven (11) players, commonly called freedom. Each team or freedom tries toput the ball as much as possible into the opponent's goal and maintain his own goal so as not to concede. According to "the game of football is thousands of years old. But the creator of this game is unknown"[1].

Football is a sport that has creativity that demands a variety of technical skills and tactics in addition to the excellent conditions of the perpetrators themselves and football also demands good technical creativity. "added that in soccer the ball is used which is round consisting of leather, and is led by a referee and assisted by two line judges"[2]. The game of football lasts two innings for 45 minutes. To play in approximately 90-120 minutes requires good physical conditions for football players, therefore physical condition is a major factor in achieving achievements in football.

Physical conditions needed in football include strength, endurance, agility, power, and flexibility. All components of physical conditions are very necessary for soccer players. This is in accordance "In the game of football there are two types of abilities that are important namely physical ability between (a) speed (b) strength (c) endurance (d) agility (e) flexibility, while the ability to master the ball such as (a) dribbling the ball (b) receiving the ball (c) kicking the ball (d) seizing the ball (e) heading the ball and (f) techniques to catch and ward off the ball specifically for the keeper'[3].

Based on the above quote, a player must have excellent physical ability and ability to master the ball based on techniques in football. Thus, the ability of players to display a variety of movements in playing football is very dependent on mastering the basic techniques that support the player's movements in the game.

As a sport that is popular among people ranging from children to adults, football has an interesting role in the principle of the game and is a sport that is fun, competitive, educating, entertaining, and can provide physical health so healthy. Then from that, the development of soccer in Indonesia in particular developed very rapidly despite the chaotic football that has not been resolved until now completely.

Warriors FC Kayu Aro Kerinci is one of the clubs in the Kerinci Regency area which carries out training activities in fostering soccer sports, one of which is U15. Training activities are carried out with very little, twice a week, face to face with the training schedule programmed by the trainer. This fondness for sports can be seen from the many communities that direct their children to involve themselves directly in every training activity. Therefore, the success of the implementation of this activity will be seen from the movement skills displayed by athletes in playing as in technical and tactic movements.

Based on the observations of researchers in the implementation of training activities on Thursday, January 30, 2016. Guiding football sports Warriors FC 
Kayu Aro Kerinci, it can be seen from many training athletes who have low basic football skills, as shown when performing technical movements in play is mastery of dribble balls that are still weak, the implementation of passing that is not yet on target between individuals and shooting accuracy that is not yet right on target. Then, from the monitoring of researchers in each championship that was followed by the FC U-15 Warrriors club, it did not show any graphic performance, on the contrary, getting results was always unsatisfactory. In this case, from the problem it is suspected that there are several factors that influence, among others: the training methods used by the trainers are not appropriate, the athlete's physical condition is still low, incomplete training facilities and infrastructure, as well as the carrying capacity of parents' socioeconomic backgrounds that are not yet relatively stable.

\section{METHOD}

This type of research is quasi-experimental. In this study did not use a control group. "The aim is to determine whether there is an effect of the treatment between cause and effect which is to know how much influence the controlled variable (independent variables and dependent variables)"[4]. "The research design used in the study is "Design Pre-test and Post-test, two groups Design"[5].

\section{A. Place and Time of Research}

The research site was conducted in Bendung Air Timur Kayu Aro Kerinci football field. when the research was conducted in May 2016.The population in this study are members of the Warriors FC Kayu Aro Kerinci which consists of several age groups namely U-10 3 U-12 6 U$1515 \mathrm{U}-1714$ people ie a total of 38 people.

\begin{tabular}{|c|c|c|c|}
\hline $\begin{array}{l}\text { Table } 1 . \\
\text { Age }\end{array}$ & Distrib & esearch & $\begin{array}{r}\text { Population } \\
\text { group }\end{array}$ \\
\hline 1. & U-10 & 3 & people \\
\hline 2. & U-12 & 6 & people \\
\hline 3. & U-15 & 15 & people \\
\hline 4. & U-17 & 14 & people \\
\hline Total & & & people \\
\hline
\end{tabular}

\section{B. Sample}

Sampling in this study was conducted by purposive sampling technique. According to "purposive determination of the sample sampling technique with certain considerations'[4]. Thus the sampling is determined on the intentions that have been determined previously. Then the researchers set a sample of the study is the U-15 Warriors FC Wood Aro Kerinci with a total of 24 people.

\section{Data Collection Instrumentation and Techniques}

To get the data in this study, a direct test of the sample was conducted. In collecting the data the researcher was assisted by Warriors FC Kayu Aro
Kerinci trainers and colleagues from FIK UNP. The data collected is primary data, that is data taken directly before the Arri Kerinci FC Warriors soccer players are given the treatment form and method of playing. The data taken is data from the results of football skills tests

(pre-test \& post-test).The source of the data obtained from the results of the measurement of football skills tests which the entire data is sourced from the FC Kayu Aro Warriors players Kerinci is being sampled.

To get the data in this study, two tests were conducted, namely the initial test (pre-test), before the player followed the training method and playing method and the final test (post-test), after the player followed the training in the form of training method and playing method for 16 meetings with exercise frequency 3-4 times a week.

\section{Data Analysis Techniques}

Data analysis technique used for hypothesis testing in this study is to use the t-test formula associated with a significant level of $5 \%$ with the formula:

$$
\begin{aligned}
& \boldsymbol{t}=\frac{\left(X_{1}-X_{2}\right)}{\sqrt{\frac{\sum D^{2}-\frac{\left(\sum D\right)^{2}}{N}}{N(N-1)}}} \\
& \text { Information: } \\
& \mathrm{X} 1=1 \text { st sample } \\
& \text { mean } \mathrm{X} 2=2 \mathrm{nd} \\
& \text { sample mean } \\
& \mathrm{D}=\text { Difference between sample scores } 1 \text { and } \\
& 2 \text { D2 }=\text { Two squares difference } \\
& \sum \mathrm{D}=\text { Total all different } \\
& \sum \mathrm{D} 2=\text { Sum of all differences that have been } \\
& \text { raised } \mathrm{N}=\text { Number of pairs }
\end{aligned}
$$

\section{RESEARCH RESULTS}

\section{A. Descriptive Research Data}

Based on the explanation and description that have been collected previously, then this chapter will explain the results of the study in accordance with the objectives and hypotheses proposed previously.

1. Pre-test groups using the form of exercise method. Group pre test using the training form method results obtained, namely a minimum value of 229 and a maximum value of 384 . From the group using the training method method obtained a mean 309 and a standard deviationof 41.18

2. Pre-test groups using the play form method. Pre-test groups using the play form method results obtained, namely a minimum value of 238 and a maximum value of 349 . From the group using the play form method obtained a mean of 307 and a standard deviation of 35.71 . 
3. Post group test using the form of exercise method. Group test post using the play form method results obtained, namely a minimum value of 296 and a maximum value of 388 . From the group using the form of the exercise method obtained a mean of 330 and a standard deviationof 28.39 .

4. Post group tests using the play form method. Post test groups that use the form of exercise the results obtained, namely a minimum value of 254 and a maximum value of 360 . From the group using the play form method obtained a mean 316 and a standard deviation of 33.36 .

\section{B. Discussion}

1. There is a significant influence of the form of training method on the basic technical abilities of $U-15$ Warriors FC Kayu Aro Kerinci football

The first hypothesis test results obtained by the method group form the initial test score: mean 309, standard deviation 41.18, minimum value 229 and maximum value

384. Final test value: mean 330, standard deviation 28.39, minimum value 296 and maximum value 388 . Based on the results of the calculation of the pre-test and post-test data using the statistical approach of the t-test, the group form of the training method had a significant influence on improving the ability of the basic technical athletes of thitung 3.97 while the t-table was 1.80 with a significant level $\alpha=0.05$ and $n=12$, then $\mathrm{t}>\mathrm{t}$ table $(3.97>1.80)$. In other words the research hypothesis proposed is significantly tested for its truth.

As stated in the previous theoretical study, the form of training method is the presentation of training material given simultaneously or as a whole, resulting in a relationship between stimulus and response. Learning by the form of exercise is very useful in motor teaching. This is due to the athlete being able to continuously repeat the material given directly, so that the athlete is expected to have more control over the material provided.

The method of training according to "states that the whole is an important principle, the whole is more than the sum of the parts"[6]. The form of training method is a method that teaches the ability to move as a unit that is intact and not broken into pieces." In the process of learning the ability of the motion, the overall method of training material is not sorted elementary or parts of the motion but is left as a whole exercise.

By this exercise the Warriors FC Kayu Aro Kerinci football player can improve on his basic technical abilities. Provision of training methods will have a positive impact on athletes to improve accuracy when performing techniques in football games, when kicking opponents, free kicks, because in training methods this form of training athletes are required to do basic technical training towards the direction or target that has been well determined.

2. There is a significant influence of the playing form method on the basic technical abilities of $U-15$ Warriors FC Kayu Aro Kerinci football
The second hypothesis test results obtained by the method group playing form initial test values: mean 307, standard deviation 35.71, minimum value 239 and maximum value 349 . Final test value: mean 316 , standard deviation 33.63, minimum value 254 and maximum value

360. Based on the results of the calculation of pre-test and post-test data using the statistical approach of the ttest the play form method group has a significant influence on improving the ability of the basic technique of athletes tcount 6.90 while the t-table is 1.80 with a significant level $\alpha=0.05$ and $\mathrm{n}=12$, then $\mathrm{t}>\mathrm{t}$ table (6.90> 1.80). In other words the research hypothesis proposed is significantly tested for its truth.

As stated in previous theoretical studies, the meaning of the word play by the wider community has been

interpreted in different ways, and sometimes the meanings are different. According to" in Jonni which has a big role in introducing play in the lives of American society, aware of the importance of playing as a way and life or a pleasant life experience and is done not to obtain solely the results and activities can be accepted by the surrounding community"[7].

The play form method is a method that teaches a psychomotor skill by demonstrating a technique and then practicing it in the game process. "Where teaching movement exercises a skill is learned starting from the beginning of the movement where there is a process of playing'[8].

In the process of training or learning that uses play methods, athletes are required to solve problems on their own, such as being active and able to perform the movements of the techniques taught.By this exercise the U-15 Warriors FC Kayu Aro Kerinci football athlete can improve his basic technical abilities. The provision of training methods to play will have a positive impact on athletes to improve their abilities during counterattacks and in arranging attacks, can position the ball against a friend in a team, because in training this form of playing methods athletes are required to play freely with variations of exercises to emphasize do basic techniques in playing good football.

\section{There is a significant difference in the effect of the} training form method and the playing form method on the basic technical abilities of U-15 Warriors FC Kayu Aro Kerinci football

The results of the third hypothesis testing based on the results of the calculation of the post test data of the two groups using the statistical approach t-test thitung 3.44 while ttable of 1.80 with a significant level $\alpha=0.05$ and $\mathrm{n}$

$=12$, then tcount $>\mathrm{t}$ table $(3,44>1.80)$. In other words the research hypothesis proposed is significantly tested for its truth.

Based on the magnitude of the effect of each independent variable on the dependent variable between the training method and play form method variables have an influence on the basic technical abilities of the U-15 Warriors FC Kayu Aro Kerinci football, this can 
be seen from the average increase in basic technical abilities through preliminary test data and final test. Increasing the average ability of football basic techniques using the form of training methods, the initial test 309 increased or farther distance at the end of the test to 330 (increased by

21) whereas in training using the playing form method, the average of the initial test 307 increased when the final test became 316 (increased by 9 ).

The results obtained from the implementation of this exercise for 16 times were felt to be running less effective because the athlete was too early to feel satisfied in doing it, 16 meetings also made this exercise boring for athletes so that the objectives to be achieved in projecting athletes over a long period of time made the athlete already feel able to do the motion.

Both of these forms of training can improve abilities when doing basic soccer techniques, but between the two exercises according to researchers and in accordance with the data and the reality in the field that training using the playing form method is more influential than training using the form training method on basic technical skills, where training using the method of playing this exercise athletes are not only required to master soccer techniques in the context of technical training, but have mastered soccer techniques in real game / match situations.

Whereas in training using the method of exercise the athlete is demanded to be more towards the targets that have been determined and often cause boredom in training. However, in training to improve the basic technical abilities of football can not be separated from the role of the athlete itself, meaning that athletes are required to be disciplined in implementing training programs so that training objectives can be obtained to the fullest.

\section{CONCLUSIONS}

Based on the results of research and hypothesis testing, the following conclusions can be drawn:

1. There is a significant influence of the form of training method on the basic technical abilities of U-15 Warriors FC Kayu Aro Kerinci football. With a tcount of 3.97 while a table of 1.80 with a significant level $\alpha$

$=0.05$ and $\mathrm{n}=12$, then tcount $>\mathrm{t}$ table $(3.97>1.80$ ). With its influence can be seen from the mean difference test where the mean pre test for the basic technical ability of the group football method of training form 309 while the post test increases or the distance goes further to 330 (increasing 21). This means that there is an increase in the basic technical abilities of football using the form of training methods.

2. There is a significant influence of the form of playing method on the basic technical abilities of U-15 Warriors FC Kayu Aro Kerinci football. With a tcount of 6.90 while a table of 1.80 with a significant level $\alpha$
$=0.05$ and $n=12$, then tcount $>t$ table $(6.90>1.80)$. With its effect can be seen from the mean difference test where the mean pre test of the basic technical ability of the form playing group method is 307 while the post test increases or the distance goes further to 316 (increasing 9). This means that there is an increase in basic technical skills using the play form method.

3. There is a significant difference in effect between the results of the training form method and the playingform method on the basic technical abilities of U-15 Warriors FC Kayu Aro Kerinci football. With a tcount of 3.44 while a table of 1.80 with a significant level $\alpha=0.05$ and $n=12$, then tcount $>t$ table (3.44> $1.80)$. Where the difference in the form of exercise method group increased by 21 whereas in the play form method 9.

\section{REFERENCES}

[1] Luxbacher, Joseph A, "Sepakbola," Jakarta; . Rajagrafindo Persada. 2012, pp, 106-130.

[2] Djezet, Darwis, "Pengajaran Sepakbola," Padang; FPOK. 1985, pp, 120-129.

[3] ' Afrizal ,S, "Handout MataKuliah Sepakbola Dasar," FIK Universitas Negeri Padang; Sukabina Press. 2013.

[4] Sugiyono, "Metode Penelitian Pendidikan," Bandung; Alfabeta. 2010.

[5] Arikunto, Suharsimi, "Prosedur Penelitian Suatu Pendekatan Praktik," Jakarta; Rineka Cipta, 2014, pp,46-58.

[6] Harsono, "Etnografi Pendidikan sebagai Desain Penelitian Kualitatif," Surakarta; Universitas Muhammadiyah. 2011.

[7] Yustisi, Hendrik, and Jonni Jonni. "Pengaruh Latihan Kecepatan dan Kelincahan Terhadap Kemampuan Dribbling,” J. JPDO. Vol.1, no. 1, pp. 108-113, May 2018.

[8] Koger, Robert, "Latihan Dasar Andal Sepakbola Remaja," Klaten; PT, Saka Mitra Kompetensi. 2007. 